\title{
The Pension Fund of Ukraine: Rethinking Risk Management during the Creation
}

\author{
Vasyl H. Fatkhutdinov \\ Doctor of Law, Associate Professor, Honored Lawyer of Ukraine, \\ Head of the Main Department of Pension Fund of Ukraine in Kyiv region \\ (Kyiv, Ukraine) \\ E-mail: mfkoorg@gmail.com \\ https://orcid.org/0000-0003-1231-5379
}

Fatkhutdinov, Vasyl H. (2020) The Pension Fund of Ukraine: Rethinking Risk Management during the Creation. Ukrainian Policymaker, Volume 6, 15-23. https://doi.org/10.29202/up/6/2

The article is dedicated to the establishment and first steps of the work of the Pension Fund of Ukraine. After the declaration of independence and the creation of a democratic new Ukraine among other issues, the question arose of the formation in Ukraine of its own financial body that would provide retirees with retirement benefits. In early 1990, a special working group was set up under the USSR Council of Ministers, and the necessary legal framework was developed during the year. On December 21, 1990, the decision was made to establish the Ukrainian Republican Branch of the USSR Pension Fund. The resolution testified not only the emergence of a new financial institution in the state, but also the beginning of new revolutionary changes in the ideology of the functioning of the pension system, which now did not rely mainly on the state budget, but received targeted sources of replenishment, its own mechanisms for their accumulation and the distribution and, most importantly, the opportunity to involve other social partners - employers and employees - in financial participation in the resolution of retirement benefits.

Keywords: pension fund, Ukraine, socio-economic processes, risk management, pension fund stabilization

Received: December 20, 2019; accepted: February 5, 2020

\section{Introduction}

According to the analysis of data collected by Soviet representatives in the international organizations, of which the USSR was a member, as well as by Soviet diplomatic missions, in the vast majority of countries the most effective source of financial resources for the pension system was not only and not so much the state budget, but the contributions from the population and target funding by the employers.

(C) Fatkhutdinov, Vasyl H., 2020 
Following the declaration of independence in Ukraine, the concept was gradually formulated that the state could not provide support to all pensioners, it could not perform such functions and that it should make these payments through close interaction with the public society (Holovatyi, 2015).

At the time in Ukraine, as a whole in the USSR, there was no its own institution that would accumulate pension funds and transfer them to citizens. In the world practice, there have already been known examples of successful work of state and non-state pension funds involved in this business. On the basis of international experience, the concept of creating a specialized financial institution was born in the Soviet Union - the USSR Pension Fund, and in May 1990 the Law on Pension Provision of Citizens of the USSR was adopted; one of the fundamental differences from its previous laws was that the payment of pensions was envisaged not from the state budget, but from a new financial institution - the Pension Fund (On pension, 1990).

The collapse of the USSR and the creation of a democratic, independent Ukraine have become the main precondition for the birth in Ukraine of its own financial body, which would form a separate financial system. The pension fund still had to be built. Therefore, its appearance in society has been received ambiguously (Fatkhutdinov, 2019).

\section{Establishment of the Ukrainian Republican Branch of the USSR Pension Fund}

In early 1990, a special working group was set up under the USSR Council of Ministers, comprising representatives of all the Union republics. During the year, the necessary legal framework was developed: the Regulations on the Pension Fund of the USSR, the instruction regulating the procedure for payment of contributions to the Pension Fund and spending its funds, and other documents.

At the same time, there was a process of forming the organizational structure of the USSR Pension Fund, which was represented at the level of the Union republics by the respective republican branches of the Fund. On December 21, 1990, the Council of Ministers of the USSR and the Ukrainian Council of Trade Unions approved joint Resolution No. 380 on the formation of the Ukrainian Republican Branch of the USSR Pension Fund (On the Establishment, 1990).

De facto, this date is considered the official date of foundation of the Pension Fund of Ukraine. The Resolution testified not only to the emergence of a new financial institution in the state, but also to the beginning of new revolutionary changes in the ideology of the functioning of the pension system, which now largely did not rely on the state budget, but received targeted sources of replenishment, its own mechanisms for their accumulation and distribution, and, most importantly, the opportunity to involve other social partners employers and employees - into financial participation in the resolution of pension issues.

From the very first days of 1991, when the USSR was still in existence, a new pension institution began to accumulate compulsory insurance payments for businesses and citizens, which allowed for the first time in December this year to finance pension expenditures at the expense of the Fund rather than the state budget.

During the year, the structure of the central apparatus of the Ukrainian Republican Branch of the USSR Pension Fund was formed, consisting of three departments, four independent units, and the audit committee. Also, in February, regional bodies of the Pension Fund were established - branch offices in the Autonomous Republic of Crimea, regions, and Kyiv city, 
which included the authorized branch representatives in districts, cities, and city districts. In addition, by the end of 1991, more than 2000 workers were employed in the system of the Republican Branch, including more than 60 specialists in the central office (Pension Fund, 2020).

\section{The creation of its independent pension system of Ukraine}

In fact, the USSR Pension Fund operated for only one year and ceased operations after the collapse of the USSR. Following Ukraine's declaration of independence in August 1991, the urgent question arose - the creation of its own independent pension system. On November 5, the same year, the Law of Ukraine "On Pension Provision" was adopted, which clearly defined the status of the Pension Fund as an independent financial and banking system (On Pension Provision, 1991). Thus the work began on the creation of the Pension Fund of Ukraine on the basis of the Ukrainian Republican Branch of the USSR Pension Fund, which ended on January 28, 1992, by the resolution of the Cabinet of Ministers of Ukraine No 39 on the creation of the Pension Fund of Ukraine based on the Ukrainian Republican Branch of the USSR Pension Fund, and on the basis of the branch offices - the divisions in the Autonomous Republic of Crimea, regions and Kyiv city (On creation, 1992).

The Pension Fund of Ukraine is the central body of the state executive power under the responsibility of the Cabinet of Ministers of Ukraine, which manages the pension finance. And just a few weeks later, the newly formed Board of the Pension Fund of Ukraine approved its own normative documents: instructions for payment of the levy, provisions on the divisions of the Pension Fund in the Autonomous Republic of Crimea, regions and Kyiv city (Pension Fund, 2020). That is, in early 1992, the legal framework for the functioning of the newly independent state's Pension Fund was fully formed (Shumsky \& Dikhtereva, 2001).

Since 1994, significant changes have taken place in the structure of the Pension Fund: it has been transformed from an independent financial and banking system to a central executive body, endowed with appropriate powers (Zaichuk, 2004). At the same time, the Fund's organizational structure has been significantly improved (Fatkhutdinov, 2019).

The status of the Pension Fund as the central body of executive power is defined by the Regulation on the Pension Fund of Ukraine, approved by the Resolution of the Cabinet of Ministers of Ukraine dated 01.06.1994 No.345 (The Question, 1994). Accordingly, the service persons and officials of the Pension Fund of Ukraine and its bodies were recognized as the civil servants (On civil service, 1993).

At the same time, Ukraine's Pension Fund employees were constantly selected and trained, and work was carried out to improve its structure and to train specialists. In 1994, during a seminar of all heads of the regional branches and heads of funds from the former USSR republics held in Mykolaiv city, it became clear that the work done in Ukraine to develop documentation and organization of the activity of the Ukrainian agency was almost the most detailed and significant compared to similar developments beyond (Kravtsov, 2011).

With the transformation of the Republican Branch into the Pension Fund of Ukraine, not only the name of the agency was changed, but also there were some changes in the process related to the mechanism of raising funds and financing the payment of pensions. In 1991, in the USSR Pension Fund, as in its Ukrainian Republican Branch, the rate of insurance payments for employers was 20.6 percent. Revenues at these tariffs in all republics and in Ukraine, in particular, did not fully meet the needs for pension payments, so redistribution and subsidies 
from the USSR Pension Fund were taking place. Moreover, having gained independence, Ukraine was no longer able to count on these grants and had to solve the problem on its own (Zaichuk, 2005).

Therefore, as of January 1, 1992, according to the government decree of January 21, 1992, the social security contribution rate for the self-financing enterprises was set at 61 percent of the payroll fund and for the budgetary institutions and organizations -37 percent (On creation, 1992). Of the total contributions, the Pension Fund received 91.6 percent and 86 percent respectively, and since May 1993, this percentage has been slightly reduced for the self-financing enterprises - from 91.6 percent to 88 percent. The rest of the money went to the Social Insurance Fund.

The tax base was the payroll fund and other payments, including in-kind, which were subject to personal income taxation. In July 1992, the administrative liability was instituted for violating the calculation and payment of social security contributions. All these measures provided an opportunity not only to finance the expenditures on pensions fully, but also to create a certain reserve of funds for the future.

It should be noted that the financing of pensions was carried out despite the termination of subsidies from the USSR Pension Fund, which at the end of 1991 owed several billion Soviet rubles to the Ukrainian Branch (Zaichuk, 2005).

It is also interesting to note that in 1991-1993 the first attempts were made to introduce elements of the expanded reproduction of pension finances inherent in cumulative pension systems (Barr, 2018). Attempts were to place temporarily free funds of the Pension Fund during the specified period to the bank deposited for gaining profit, to deposit into the authorized funds of enterprises, to use for granting loans, etc. (Milan, 2020).

Such actions, while providing some income to the Pension Fund, were not entirely successful in terms of administration and proper legal support and were discontinued in mid1993. At that time, the Pension Fund money had been scattered across 12 banks. This did not affect the work in the best way. After all, when it was necessary to transfer excess cash from one place to another, the banks interfered, causing delays in the payment of pensions.

Therefore, in December 1993, in order to create conditions for reducing the period of circulation of funds intended for payment of pensions, financial assistance, and postal remittances, to ensure their timely payment, with the participation of the Pension Fund the Joint-Stock Postal-Pension Bank Aval was created, associated with all these payments (Joint Stock, 2020). The Fund itself was reformed. It began with a change in the structure of the central office. The divisions were created: budgetary, pension, revenue, control and audit, computerization, as well as human resources, financial, legal, organizational and media relations, case management (Zaichuk, 2005).

The Fund itself was transformed from an independent financial and banking system to a central executive body and endowed with appropriate powers. The status of the Pension Fund as the central body of executive power was determined by the Regulation on the Pension Fund of Ukraine, approved by the Cabinet of Ministers of Ukraine Resolution No. 345 of 01.06.1994 (The Question, 1994). Respectively, the service persons and officials of the Pension Fund of Ukraine were recognized as civil servants. According to this regulation, there were established units of the Pension Fund of Ukraine in districts, cities, and city districts (Fatkhutdinov, 2019).

Thus, a vertical structure of the Pension Fund management was created, which fully corresponded to the administrative and territorial structure of the state, as well as to structures 
of other state bodies, which had similar functions for collecting obligatory payments (bodies of tax and audit services).

An important step was to streamline the financial flows in the Pension Fund system, as well as to resolve issues related to the cash settlement of its funds. Until 1994, there had been a rather inconvenient system of financing pension payments. The procedure for transferring funds had been complicated and too cumbersome. Funds collected from taxpayers in districts and cities were channeled to the Regional Divisions of the Pension Fund and subsequently distributed between the areas according to the needs for financing the payment of pensions.

At the same time, funding was provided through social protection bodies, and they transferred funds to postal companies for direct payment of pensions to pensioners. Also, in different regions, the Pension Fund was serviced by various banks, which created additional problems, the main one being that it sometimes took several weeks for money to circulate. This made it challenging to finance pension payments and took a lot of time to find money in numerous bank accounts.

Therefore, in May 1994, the mechanism of financing the payment of pensions was radically changed, and the procedure was introduced, according to which insurance contributions were accumulated in the accounts of the district and city units of the Fund and at this very level were directed to pension payments, and transfers of funds along the route "district-region" and, even more so, "region-center" occurred only in case of need for redistribution of funds due to their lack or surplus.

A direct transfer of funds by the Pension Fund bodies to postal companies was also introduced. The social protection bodies were only required to provide information lists and applications for payment of pensions. With the introduction of such a mechanism, the bodies of the Pension Fund immediately felt its effectiveness, were able to increase the efficiency of the disposal of funds, and their movement became more transparent, it became easier to control. The introduction of the new pension payment mechanism was carried out at the same time as the concentration of the accounts of the bodies of the Pension Fund in one bank - the Joint-Stock Postal-Pension Bank Aval.

Thus, within one bank not only the movement of funds in the Pension Fund system was concentrated, but also the Fund's calculations with the postal companies, which accelerated the process of their circulation from the payer of insurance contributions to the pensioner, and therefore significantly increased the possibilities of rational use of the Pension Fund's money. In particular, the possibility of rapid redistribution of money between regions and between districts and cities. For example, under the new financing system, the funds that were received in the morning from a payer to a district unit in Zaporizhzhia region and where they were a surplus, were paid on the same day as a pension in Chernihiv region, where there was not enough money.

In the mid-1990s, lack of funds to pay pensions became a widespread phenomenon due to the stagnant economy and barter calculations. The Pension Fund often had to pay pensions to people in kind instead of cash payments. The needs of the people were analyzed, lists were drawn up: some of the pensioners needed to renovate the house at the expense of the pension, and someone might agree to some goods. In total, there were 78 types of pensions in kind at that time. Thanks to this, we can say that the process of workers' pension provision was continuous. That testified to the effectiveness of the actual mechanism of the pension system (Martynenko, 2017). It was preserved after the transition of the Pension Fund's bodies to the Oshchadbank. 


\section{The Basic Directions of Reforming Pension Provision (1995-1998)}

In 1994-1997, under the state budget laws for those years, the Pension Fund was included in the state budget. At that time, the phenomenon of non-payment to the Pension Fund was widespread against the background of the deep economic crisis that gave rise to the shadowing of the economy and unemployment (Bazaluk, 2016). The financial base of the pension system was undermined and deformed.

The negative impact on its financial status was made by imposing on the expenditures of the Pension Fund necessity to finance pensions to certain categories of citizens in accordance with numerous laws adopted over those years that governed the provision of pensions together with the Basic Law on Pension Provision. For example, the Laws of Ukraine "On Civil Service” adopted on December 16, 1993 (On Civil Service, 1993); “On Local SelfGovernment in Ukraine” passed on May 21, 1997 (On Local Self-Government, 1997), “On General Prosecutor's Office” adopted on November 5, 1991 (On General Prosecutor's Office, 1991); etc.

In addition, at different times, the Fund financed social payments that were not related to the pension system at all, and by their nature would have to be paid at the expense of the budgetary funds - child support, additional payments for caring over the disabled persons, etc.

Funding pensions for preferential treatment in relation to harmful working conditions from the Pension Fund money can also be attributed to negative factors. Since 1992, such workers' retirement benefits have been significantly expanded. At the same time, despite the obligation to reimburse the Fund's relevant expenses by the enterprises with these conditions, the real level of reimbursement of pension costs under the so-called List No 2 in the late 1990s averaged only 30 percent.

As a result, since 1995, pension arrears have arisen. This is despite the fact that the level of pension provision remained low, and its differentiation depending on the employee's labor contribution was actually lost.

All this has shaped society's awareness of the need for pension reform. However, for its implementation, it was necessary to overcome acute crisis phenomena in the pension system itself. Therefore, the main task of the Pension Fund in the second half of the 1990s was the financial stabilization of the pension system, the elimination of pension arrears, and the creation of the necessary preconditions for pension reform.

The main directions of work of the Pension Fund during this period were improvement of the legislation on payment of obligatory payments, the introduction of their personified accounting, strengthening of payment discipline of enterprises, exemption of the Fund from general expenses. That is, in the system of the Pension Fund at this time, the new directions of management started to be introduced (Romanenko \& Chaplay, 2016), which were subsequently realized into the other state bodies.

In fact, the first step to reduce the debt of mandatory payments to the Pension Fund was an approval on September 6, 1996, the Resolution of the Pension Fund of Ukraine No. 11-1 of the "Instruction on the procedure for calculation and payment by enterprises, institutions, organizations and citizens of insurance contributions to the Pension Fund of Ukraine, as well as accounting for the receipt and spending of its funds" (On approval, 1997), which determined that contributions to pension insurance are paid at the same time as the receipt of funds at the bank's institutions. At the same time, in case of insufficient funds, the issuance by the banks of money for wages and transfers of contributions to the Pension Fund should be carried out 
in proportionate amounts. There was also introduced the right of the heads of the subordinate bodies of the Pension Fund to suspend the operations of enterprises, institutions, organizations, private entrepreneurs within the accounts in the banks in case of refusal of such legal entities and individuals to register as payers of contributions to the Pension Fund.

In 1997, active work began on major pension reform bills. The Law of Ukraine "On Obligatory State Pension Insurance Fee" was adopted, according to which the collection rate for the pension insurance system was set at 32 percent of the wage fund (On Obligatory 1997). Measures were also taken during that period to settle the arrears of the payment of compulsory state pension insurance by self-produced products (On approval, 1997). Collective rural agricultural enterprises massively plowed the private plots of pensioners with their consent at the expense of part of the pension, issued grain and other agricultural products - flour, sugar, as well as industrial goods - TVs, refrigerators, gas pipes, plates and counters, firewood, briquettes, various everyday goods.

By Resolution of the Cabinet of Ministers of Ukraine of April 21, 1998 No. 525 "On urgent measures for repayment of arrears of wages, financial provision, pensions, scholarships, and other social payments" (On urgent, 1998), and the Law of Ukraine On Amendments to the Law of Ukraine "On Obligatory State Pension Insurance Fee" adopted on October 22 of that year (On Amendments, 1998) there were introduced additional rates for the compulsory state pension insurance. At the same time, a specialized state-owned enterprise of the Pension Fund of Ukraine was created in order to fulfill the functions of realization of goods (services), property, property rights transferred at the expense of the collection for compulsory state pension insurance.

Considerably contributed to the filling of the Pension Fund's budget the adoption of the Cabinet of Ministers of Ukraine Resolution "On the state and additional measures for payment of pensions, repayment of debt from obligatory payments to the state and local budgets, arrears to the Pension Fund and the Fund for the implementation of measures for elimination of consequences of the Chornobyl disaster and social protection of the population" (On the state, 1998). At the Cabinet of Ministers of Ukraine and regional administrations, the standing committees were established to settle the debts on paying contributions to the Pension Fund, which considered each fact of the debt and the ways of its repayment. In addition to the measures towards the management of the debtor enterprises, the non-traditional sources of filling the budget of the Pension Fund were used.

Thus, a mechanism for repayment of in-kind pension arrears by the products of debtors was introduced. Due to such actions, the debt to the Fund was paid off in the amount of over UAH 800 million.

\section{Conclusions}

1. Complex and ambiguous socio-economic processes of the second half of the 1980s caused the transition from the Soviet system of pension provision of citizens to the pan-European one, as evidenced by the creation of the USSR Pension Fund as a separate specialized financial institution. It was the very institution called for the accumulation of funds to provide pension payments to Ukrainian citizens.

2. However, the formation of an independent Ukrainian state has put on the agenda the question of organizing its own financial institutional structure, which could ensure the realization of the state function in the field of pension payments to Ukrainian 
citizens. This necessitated the creation of its own Pension Fund of Ukraine, which should function in the difficult realities of the early 1990s, which were marked by hyperinflation, an imbalance of the economic situation, lack of control over the flow of funds to the Pension Fund of Ukraine, etc.

3. Therefore, the main activities of the Pension Fund of Ukraine in the first half of the 90's were: professionalization of employees, social insurance, repayment of debts to the Fund, search for a reliable banking structure (Bank Aval), which could provide pensions to citizens.

\section{[ㅁ] References}

Barr, N. (2018) Pension Systems: Principles, Debates, and Analytical Errors. In: Macmillan Publishers Ltd (eds) The New Palgrave Dictionary of Economics. Palgrave Macmillan, London. https://doi.org/10.1057/978-1-349-95189-5

Bazaluk, O. (2016) Corruption in Ukraine: Rulers' Mentality and the Destiny of the Nation, Geophilosophy of Ukraine. Cambridge Scholars Publishing.

Fatkhutdinov, V. (2019) Pension Legislation of Ukraine: Current State and Development Prospects. Ukrainian Policymaker, Volume 5, 24-33. https://doi.org/10.29202/up/5/3

Holovatyi, Mykola (2015) The state and society: The conceptual foundations and social interaction in the context of formation and functioning of states. Economic AnnalsXXI, 9-10, 4-8.

Joint Stock Company Raiffeisen Bank Aval (2020) Available online: https:/ex.aval.ua/en/ about/ (accessed on March 17, 2020).

Kravtsov, D. (2011) Organization of work in the bodies of the Pension Fund of Ukraine. Kharkiv: National University "Law Academy of Ukraine," 2011.

Martynenko, N. (2017) Development of the Pension System of Ukraine: concept and essence. Public Administration and Local Government, 3 (34), 55-61.

Milan, M. (2020) Demographic Changes, Pension Reforms, and Absolute Surplus Value: Intertemporal Exploitation in Contemporary Capitalism?. In: Silver M. (eds) Confronting Capitalism in the 21st Century. Palgrave Macmillan, Cham. https://doi. org/10.1007/978-3-030-13639-0_15

On Amendments to the Law of Ukraine "On Obligatory State Pension Insurance Fee" (1998) Law of Ukraine. Information of the Verkhovna Rada of Ukraine 42, p. 257. Available online: https://zakon.rada.gov.ua/laws/show/64-14?lang=en (accessed on March 17, 2020).

On approval of the List of seasonal works and seasonal industries (1997) Resolution of the Cabinet of Ministers of Ukraine of March 28, 1997 No. 278. Available online: https:// zakon.rada.gov.ua/laws/show/278-97-\%D0\%BF?lang=en (accessed on March 17, 2020).

On approval of the Instruction on the procedure for calculation and payment by enterprises, institutions, organizations and citizens of insurance contributions to the Pension Fund of Ukraine, as well as accounting for the receipt and spending of its funds (1997) Resolution of the Pension Fund of Ukraine N 5-4 (z0321-97) of 7/29/97. Available online: https:// zakon.rada.gov.ua/laws/show/z0550-96?lang=en (accessed on March 17, 2020).

On Civil Service (1993) Law of Ukraine. Information of the Verkhovna Rada of Ukraine, No 52, Art.490. Available online: https://zakon.rada.gov.ua/laws/show/3723-12 (accessed on March 17, 2020). 
On Creation of the Pension Fund of Ukraine (1992) Resolution of the Cabinet of Ministers of Ukraine of January 28, 1992. Available online: https://zakon.rada.gov.ua/laws/ show/39-92-\%D0\%BF (accessed on March 17, 2020).

On Establishment of the Ukrainian Republican Branch of the USSR Pension Fund (1990) Resolution No. 380 of the Council of Ministers of the Ukrainian SSR and the Council of the Federation of Independent Trade Unions of Ukraine of December 21, 1990. Available online: https://zakon.rada.gov.ua/laws/show/380-90-\%D0\%BF?lang=en (accessed on March 17, 2020).

On General Prosecutor's Office (1991) Information of the Verkhovna Rada of Ukraine 53, p.793. Available online: https://zakon4.rada.gov.ua/laws/show/1789-12/page?lang=en (accessed on March 17, 2020).

On Local Self-Government in Ukraine (1997) Law of Ukraine. Information of the Verkhovna Rada of Ukraine 48, p. 170. Available online: https://zakon.rada.gov.ua/laws/ show/280/97-\%D0\%B2\%D1\%80?lang=en (accessed on March 17, 2020).

On Obligatory State Pension Insurance Fee (1997) Law of Ukraine. Information of the Verkhovna Rada of Ukraine 37, p. 237. Available online: https://zakon.rada.gov.ua/ laws/show/400/97-\%D0\%B2\%D1\%80?lang=en (accessed on March 17, 2020).

On pension provision of citizens in the USSR: The Law of the USSR of May 15 (1990) Information of the Verkhovna Rada, No. 23, Art. 416.

On Pension Provision (1991) Law of Ukraine of 05.11.1991 No.1788-X. Available online: https://protocol.ua/ua/pro_pensiyne_zabezpechennya/ (accessed on March 17, 2020).

On the state and additional measures for payment of pensions, repayment of debt from obligatory payments to the state and local budgets, arrears to the Pension Fund and the Fund for the implementation of measures for elimination of consequences of the Chornobyl disaster and social protection of the population (1998) Resolution of the Cabinet of Ministers of Ukraine of August 11, 1998, No 1251. Available online: https:// zakon.rada.gov.ua/laws/show/1251-98-\%D0\%BF?lang=en (accessed on March 17, 2020).

On urgent measures to pay back arrears of wages, cash, pensions, scholarships, and other social benefits for 1998 (1998) Resolution of the Cabinet of Ministers of Ukraine of April 21, 1998, No. 525. Available online: https://ips.ligazakon.net/document/view/ KP980525?an=1 (accessed on March 17, 2020).

Pension Fund of Ukraine (2020) Available online: https://www.pfu.gov.ua/ (accessed on March 17, 2020).

Romanenko, Y., Chaplay, I. V. (2016) The essence and specifics of the services marketing system in the mechanisms of public administration. Actual Problems of Economics, 186(12), 81-89.

Shumsky, V.M., Dikhtereva, V.V. (2001) Forming a Pension Fund: The Reality of Potential Sources. Finance of Ukraine 7, 58-61.

The Question of the Pension Fund of Ukraine (1994) Resolution of the Cabinet of Ministers of Ukraine of June 1, 1994. N 345. Available online: https://zakon.rada.gov.ua/laws/ show/345-94-\%D0\%BF/ed19940601 (accessed on March 17, 2020).

Zaichuk, B. (2004) Legal Principles of the Pension Fund of Ukraine. Law of Ukraine 8, 49-53. Zaichuk, B. (2005) The Pension Fund of Ukraine: Yesterday and Today. Bulletin of the Pension Fund of Ukraine 12, 6-7. 